\title{
Hydrolysis of Soybean Protein Improves Iron Bioavailability by Caco-2 Cell
}

\author{
Ying Lv ${ }^{1,2}$, Shuntang Guo ${ }^{3}$, Elad Tako ${ }^{4}$, Raymond P. Glahn ${ }^{4, *}$ \\ ${ }^{1}$ Beijing Laboratory of Food Quality and Safety; Beijing Key Laboratory of Agricultural Product Detection and Control of Spoilage \\ Organisms and Pesticide Residue, Beijing, China \\ ${ }^{2}$ College of Food Science and Engineering, Beijing University of Agriculture, Beijing, China \\ ${ }^{3}$ College of Food Science \& Nutritional Engineering, China Agricultural University, Beijing, China \\ ${ }^{4}$ Department of Food Science, and USDA-Agricultural Research Service, Robert W. Holley Center for Agriculture and Health, Cornell \\ University, Ithaca, NY, United States of America \\ *Corresponding author: rpg3@cornell.edu
}

Received April 05, 2014; Revised April 24, 2014; Accepted May 03, 2014

\begin{abstract}
Iron is an important trace metal element in human body. Iron deficiency affects human health, especially pregnant women and children. Soybean protein is a popular food in Asia and contains a high amount of iron (145.70 $\pm 0.74 \mu \mathrm{g} / \mathrm{g})$; however, it is usually reported as an inhibitor of iron absorption. In this study, the effect of hydrolysis on iron bioavailability of soybean protein was investigated with an in vitro digestion/Caco-2 cell model. The result showed that hydrolysis significantly enhanced the intrinsic and extrinsically added iron bioavailability of soybean protein $(P<0.05)$. Furthermore, the hydrolyzed soybean protein $(\mathrm{SPH})$ was ultrafiltered to different molecular weight of peptides; and intrinsic iron content of SPH ( $>10 \mathrm{kDa})$, as well as the iron uptake by Caco-2 cells, significantly higher than that of low molecular weight of SPH. However, when extrinsic iron was added, the $\mathrm{SPH}(<1 \mathrm{kDa})$ were presented with highest iron bioavailability. These results indicated that hydrolysis of soybean protein improves iron bioavailability.
\end{abstract}

Keywords: iron bioavailability, hydrolysis, soybean peptides, Caco-2 cells

Cite This Article: Ying Lv, Shuntang Guo, Elad Tako, and Raymond P. Glahn, "Hydrolysis of Soybean Protein Improves Iron Bioavailability by Caco-2 Cell.” Journal of Food and Nutrition Research, vol. 2, no. 4 (2014): 162-166. doi: 10.12691/jfnr-2-4-5.

\section{Introduction}

Iron is an important trace metal element in the human body, and many food components can affect iron absorption. Soybean protein has been mostly reported as an iron absorption inhibitor [1,2], while there are also some researches showed that the iron bioavailability of fermented soybean foods was greatly improved. The effect of a variety of traditional oriental unfermented and fermented soy products on iron absorption was investigated in Indian women, and iron absorption was found significantly increased with natto, soybean miso, tempe, and silken tofu [3]. In connection with this, relatively high iron absorption from NaFeEDTA-fortified soy sauce was reported [4]. Soy sauce is a commonly consumed condiment in the diet of Chinese, and thus used as a vehicle for iron fortification. NaFeEDTA-fortified soy sauce was presented with high efficiency in controlling iron deficiency and improving iron status for both adults and children in a population based intervention trial $[5,6]$. During the fermentation process, the soy protein is transformed into a mixture of amino acids and peptides, which might be associated with the enhancing effect of iron absorption [7]. However, it is still unclear that the positive role of fermented soy food on the enhancement of iron bioavailability is due to the forming of some kind of amino acid and peptides.

It was reported that some animal proteins or peptides can promote iron absorptions. Small amounts of meat $(\geq$ 50 g) significantly increase nonheme-iron absorption from a phytate-rich meal low in vitamin C [8]. Moreover, some milk peptides obtained by in vitro digestion were reported to increase the iron dialyzability and then promote iron uptake by Caco-2 cells $[9,10]$. Likewise, as to the soybean protein, the research on the interaction between soybean protein hydrolysates and iron investigated with immobilized metal chromatography affinity revealed that soybean protein hydrolysates could form a complexes with iron [11]. Hence, it seems that hydrolysis might influence iron bioavailability of soybean protein.

In this study, the hydrolyzed soybean protein was obtained with trypsin, and then an in vitro digestion/Caco2 cell model was used to determine the effect of hydrolysis on iron bioavailability of soybean protein. This research also documents the difference of intrinsic and extrinsically added iron bioavailability of hydrolyzed soybean protein. Furthermore, the effect of different molecular weight of hydrolyzed soybean protein on iron bioavailability was discussed. 


\section{Materials and Methods}

\subsection{Materials}

Unless otherwise stated, all reagents were purchased from Sigma Chemical Co. (St. Louis, MO).

\subsection{Sample Preparation}

Soybeans were purchased in local markets of Ithaca NY. Soybeans (80 g) were ground to flour, and then 400 $\mathrm{mL}$ of hexane was added and stirred for 30 min to extract soy oil. At the end of every stirring period, the hexane phase was removed from the soybean flour, and fresh solvent was added to the precipitate. The extraction procedure was repeated three times. Then, the hexane was evaporated and removed from the powder at room temperature. The remaining powder was named as defatted soybean flour. The soybean protein isolates were extracted from the defatted soybean flour as previously described [12]. All of these prepared proteins were cooked (121 $\left.{ }^{\circ} \mathrm{C}, 15 \mathrm{~min}\right)$.

\subsection{Effect of Hydrolysis on the Iron Bioavailability of Soybean Protein}

The prepared cooked soybean protein $(0.25 \mathrm{~g})$ was dissolved in $10 \mathrm{~mL}$ of deionized water, and then the $\mathrm{pH}$ was adjusted to 7.0. After being hydrolyzed with pancreatin (enzyme:substrate=1:70; w: w) for $2 \mathrm{~h}, 4 \mathrm{~h}, 6 \mathrm{~h}$ at $37^{\circ} \mathrm{C}$, the resultant solution, as well as the soybean protein, was heated in a boiling water bath for 10 min to inactive the pancreatin. Thus, the samples used for this study were intact soybean protein (SPI) and the hydrolyzed soybean protein (SPH) for $2 \mathrm{~h}, 4 \mathrm{~h}$ and $6 \mathrm{~h}$. After that, those samples underwent in vitro digestion.

\subsection{Effect of Extrinsic Iron on the Iron Bioavailability of SPH.}

This study was to compare the iron bioavailability of SPI and SPH (hydrolyzed with pancreatin for 4h) when extrinsic iron was added. The final iron concentration was $12.6 \mathrm{mg} / \mathrm{L}$. The iron used here was from stock solutions of $\mathrm{FeCl}_{3}$ of $1040 \mu \mathrm{g}$ of $\mathrm{Fe} / \mathrm{mL}(18.6 \mathrm{~mol} / \mathrm{L})$ in $0.1 \mathrm{~mol} / \mathrm{L} \mathrm{HCl}$ (Sigma 1-9011). After that, the prepared samples underwent in vitro digestion.

\subsection{The Effect of SPH with Different Molecular Weight on the Iron Bioavailability}

After SPI solution was hydrolyzed with pancreatin for $4 \mathrm{~h}$, it was centrifuged at $3,000 \times \mathrm{g}$ for $20 \mathrm{~min}$. The supernatant was then used to separate different molecular weight of SPH. Membranes of molecular weight cut-offs (MWCO) of $1 \mathrm{kDa}, 3 \mathrm{kDa}, 10 \mathrm{kDa}$, and $30 \mathrm{kDa}$ (Millipore, Billerica, MA) were used for ultrafiltering. First, the supernatant was ultrafiltered with membranes of MWCO of $30 \mathrm{kDa}$. The retentate containing peptides with molecular weight $>30 \mathrm{kDa}$ was collected and diluted with distilled water, and subsequently ultrafiltrated with membrane of $30 \mathrm{kDa}$ again. This process was repeated twice to remove the SPH with molecular weight lower than that of $30 \mathrm{kDa}$. The retentate was collected and named as SPH (> $30 \mathrm{kDa}$ ). Second, the permeate containg peptides with molecular weight $<30 \mathrm{kDa}$ was ultrafiltrated with membrane of $10 \mathrm{kDa}$. The retentate of peptides with molecular weight between 10 and $30 \mathrm{kDa}$ was collected and diluted with distilled water, and subsequently ultrafiltrated with membrane of $10 \mathrm{kDa}$ twice to remove the SPH with molecular weight lower than that of $10 \mathrm{kDa}$. The retentate was named as SPH (10$30 \mathrm{kDa})$. Finally, the SPH (3-10 kDa), SPH (1-3 kDa), and $\mathrm{SPH}(<1 \mathrm{kDa})$ were prepared with membranes of MWCO of $1 \mathrm{kDa}, 3 \mathrm{kDa}, 10 \mathrm{kDa}$ as the above method. All the samples were collected and lyophilized. The prepared different molecular weight of SPH $(0.125 \mathrm{~g})$ was added with $10 \mathrm{~mL}$ of $140 \mathrm{mmol} / \mathrm{L} \mathrm{NaCl}, 5 \mathrm{mmol} / \mathrm{L} \mathrm{KCl}, \mathrm{pH} 2.0$ solution to initiate the in vitro digestion process.

\subsection{Cell Culture}

Caco-2 cells were obtained from the American Type Culture Collection (Rockville, MD) at passage 17 and used in experiments at passages 25-33. Cells were seeded at a density of 50,000 cells $/ \mathrm{cm}^{2}$ in collagen-treated sixwell plates (Costar Corp. Cambridge, MA). The cells were grown in Dulbecco's Modified Eagle Medium (GIBCO, Grand Island, NY) with 1:10 (v/v) fetal calf serum (GIBCO), $25 \mathrm{mmol} / \mathrm{L}$ HEPES. The cells were maintained at $37{ }^{\circ} \mathrm{C}$ in an incubator with a $\mathrm{CO}_{2} /$ air (5:95) atmosphere at constant humidity, and the medium was changed every 2 days. The cells were used in the iron uptake experiments at 13 days postseeding. Under these conditions, the amount of cell protein measured in each well was found to be highly consistent from well to well within each culture plate. On day 12 postseeding, the growth medium was removed from the cell culture plates, the plates were washed once with $2 \mathrm{~mL}$ of MEM (Minimum Essential Medium, GIBCO) at $\mathrm{pH} 7.0$, and then an additional $2 \mathrm{~mL}$ of MEM was added; the cells were returned to the incubator until use the following day. Immediately prior to use in the experiment, the cells were again washed with MEM and exactly $1.0 \mathrm{~mL}$ of MEM was placed on each monolayer. After that, an insert ring with attached dialysis membrane was then placed in each well. This MEM was chosen because it contained no added $\mathrm{Fe}$ and, upon formulation with the added ingredients, was always found to contain $\mathrm{Fe}<8 \mu \mathrm{g} / \mathrm{L}$. The MEM was supplemented with $10 \mathrm{mmol} / \mathrm{L}$ PIPES (piperazine- $N, N^{\prime}$-bis[2-ethanesulfonic acid], antibiotic-antimycotic solution (10 g/L $)$, hydrocortisone $(4 \mathrm{mg} / \mathrm{L})$, insulin $(5 \mathrm{mg} / \mathrm{L})$, selenium (5 $\mathrm{mg} / \mathrm{L})$, triiodothyronine (4 mg/L), and epidermal growth factor (20 mg/L), all from Sigma Co.

\subsection{In Vitro Digestion}

The in vitro digestion protocol was performed as described previously [13]. Briefly, peptic and intestinal digestions were prepared for each food sample. Aliqouts $(1.5 \mathrm{~mL})$ of the intestinal digest were placed in the upper chamber of each well. As per our previously published diagrams, the "upper chamber" was created by attaching a dialysis membrane (15 kDa MWCO) to an insert ring. The Caco-2 cells are cultured below this membrane on the plastic surface of the culture plate for each well. Iron from samples placed in the upper chamber can dialyze through the membrane and be accessible for uptake by the Caco-2 cells. Ferritin formation by the Caco-2 cells, a marker for 
cell Fe uptake, is used as the indicator of $\mathrm{Fe}$ bioavailability.

\subsection{Chemical Analyses}

Cell protein was assessed using a Bio-Rad DC protein assay kit (Bio-Rad, Hercules, CA) based on the Lowry assay. Caco-2 cell ferritin was assessed using a commercially prepared assay kits (FER-IRON II Ferritin Assay; RAMCO Laboratories, Houston, TX) with an automatic $\gamma$ counter Wizard Wallac 1480 (Perkin-Elmer, Norwalk, CT). Iron concentrations were determined with an inductively coupled argon plasma emission spectrometer (ICP-ES, model 61E Trace Analyzer, Thermo Jarrell Ash Corp., Franklin, MA).

\subsection{Statistical Analyses}

Data were analyzed using the software package JMP 5.1 and/or GraphPad Prism (GraphPad Software, San Diego, CA). Analysis of variance (ANOVA) with Turkey's post-test was used to compare differences among means. All of the experiments included six replicates $(n=6)$ unless otherwise stated. Differences among means were considered significant at $P<0.05$.

\section{Result and Discussion}

\subsection{Effect of Hydrolysis of Soybean Protein on Iron Bioavailability with Intrinsic or Extrinsic Iron}

Figure 1 showed the ferritin concentrations in Caco-2 cells treated with SPI and SPH of different times. Compared to the SPI, iron uptake of soybean protein increased by about 25\% after being hydrolyzed for 4 to $6 \mathrm{~h}$ $(p<0.05)$, while no obvious difference was presented between 4 and 6h. In Figure 2, in comparison to SPI, the iron bioavailability of the SPH being hydrolyzed for $4 \mathrm{~h}$ was more than $90 \%$ greater when extrinsic iron (final concentration of $12.6 \mathrm{mg} / \mathrm{L}$ ) was added to the sample $(p<0.01)$.

Soybean protein can bind with iron and reported as an inhibitor of iron absorption. In the research about iron absorption of traditional oriental unfermented and fermented soy products, a reverse correlation between iron absorption and high molecular weight fraction of the soybean protein was found [3]. Also, it was reported that the higher of the molecular weight of the soybean protein, the greater amount was their chelating with iron [11]. Thus, it seems that high molecular weight of soybean protein per se reduce iron bioavailability. Although hydrolysis might change the structure of the soybean protein, the intrinsic iron may still be bound by high molecular weight of soybean protein too tight to be released. Hence, hydrolysis of soybean protein just increased the intrinsic iron uptake by about 25\% (Figure 1). When additional iron was added to make the final iron content of $12.6 \mathrm{mg} / \mathrm{L}$, high molecular weight of soybean protein could bind with iron to their high amount, and there is still some free iron existed. However, Figure 2 shows there are no obvious difference between the iron uptakes of SPI with iron and $\mathrm{FeCl}_{3}(12.6 \mathrm{mg} / \mathrm{L})$. This might be the reason of some substances released from the
SPI with iron sample during the process of in vitro digestion, which may enhance iron bioavailability. Also, at the same amount of iron content, the iron bioavailability of SPH with iron (being hydrolyzed with pancreatin for 4h) is significantly higher than that of SPI with iron; this further provides evidence that it is the substances released during the hydrolysis improve iron uptake by Caco-2 cells because SPH underwent hydrolysis before in vitro digestion. Relatively high iron absorption was reported from consumption of iron fortified soy sauce $[5,6]$. Thus, it seems that extrinsic added iron and hydrolysis of soybean protein could obviously promote iron bioavailability.

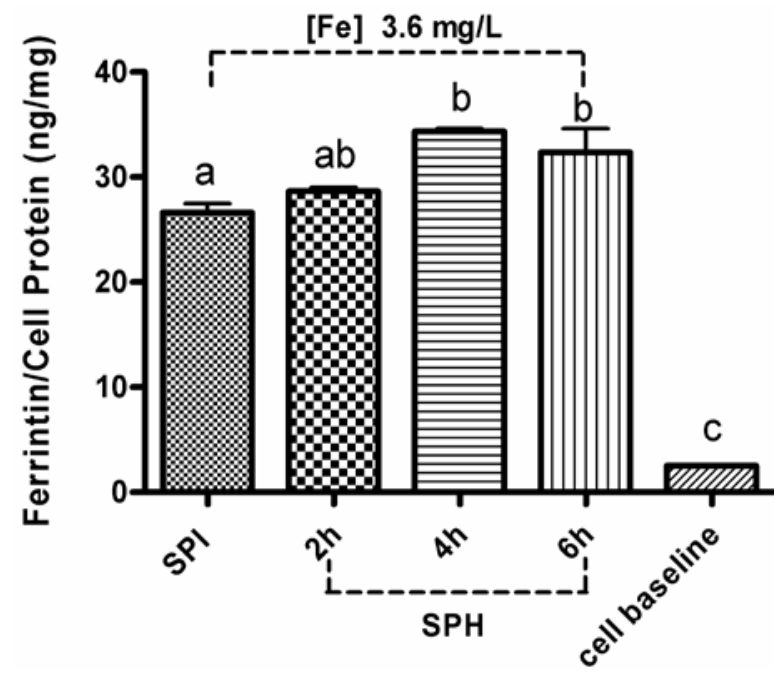

Figure 1. Cell ferritin formation in response to SPI and SPH with different hydrolyzed time. SPI: intact soybean protein; SPH: hydrolyzed soybean protein. The iron concentration in all samples is as same as 3.6 $\mathrm{mg} / \mathrm{L}$. Values are mean \pm SEM $(n=6)$. Bars with no letters in common are significantly different $(P<0.05)$

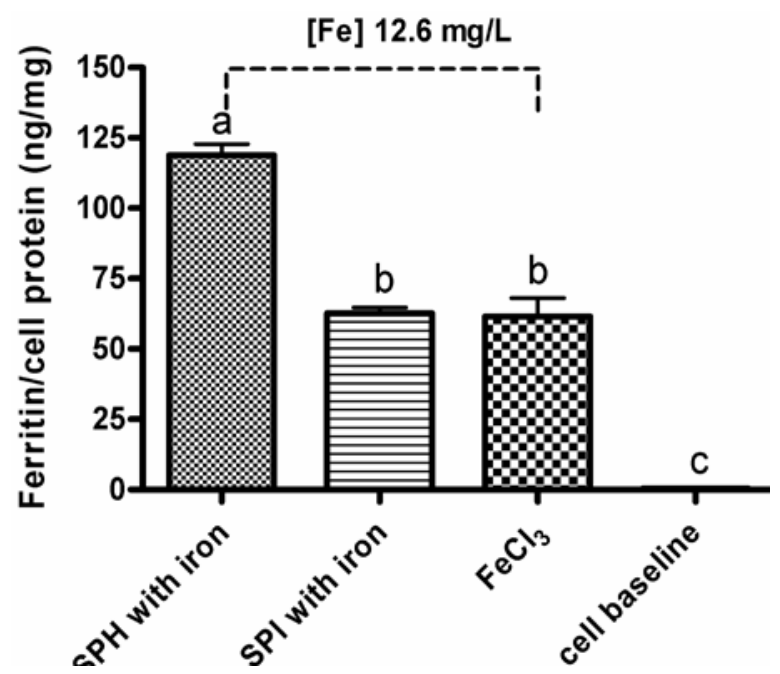

Figure 2. Cell ferritin formations in response to SPI and SPH with extrinsic iron. The final iron concentration is $12.6 \mathrm{mg} / \mathrm{L}$. SPI: intact soybean protein; SPH: hydrolyzed soybean protein. Values are mean \pm SEM $(n=6)$. Bars with no letters in common are significantly different $(P<0.05)$

Both soybean and milk protein was usually considered as inhibitors of nonheme iron absorption [2,14]. However, many peptides with some special amino acid, such as Cys, His, Glu and Asp, formed during proteolytic digestion were reported with high iron bioavailability $[15,16]$. In particular, some peptides isolated from milk digestion, as 
well as synthetic $\beta$-casein peptides, were also reported to exert a positive effect on iron bioavailability [8,9]. It seems that the peptides from various proteins might have different positive effects on iron uptake. Thus, the higher iron bioavailability of SPH might be due to the soybean peptides. Compared to the SPI with iron, the increased promotive effect of the SPH with iron on iron uptake by Caco-2 cells might due to the formation of much more peptides before in vitro digestion.

\subsection{Effect of SPH with different molecular weight on iron bioavailability}

The iron contents of SPH with different molecular weight are illustrated in Table 1. High molecular weight of peptides prone to bind much more iron. Figure 3 showed the uptake of intrinsic iron in SPH with different molecular weight. High molecular weight of SPH (10-30 $\mathrm{kDa}$ and $>30 \mathrm{kDa}$ ) was presented with greater iron uptake, and the ferritin obtained with the SPH $(<1 \mathrm{kDa}, 1-3 \mathrm{kDa}$, and 3-10 $\mathrm{kDa}$ ) was very close to that of the baseline without any treatment. However, when extrinsic iron was added (concentration of $6.3 \mathrm{mg} / \mathrm{L})$, the $\mathrm{SPH}(<1 \mathrm{kDa})$ caused greater ferritin formation than all the other fractions (Figure 4). These results suggested that the iron bioavailability promoter might exist in the low molecular weight of SPH.

Table 1. Iron concentrations of SPI and SPH with different molecular weight

\begin{tabular}{cc} 
& Iron content (ug/g) \\
$\mathrm{SPI}$ & $145.70 \pm 0.74^{\mathrm{b}}$ \\
$\mathrm{SPH}(<1 \mathrm{kDa})$ & $26.76 \pm 2.5^{\mathrm{a}}$ \\
$\mathrm{SPH}(1-3 \mathrm{kDa})$ & $38.71 \pm 1.61^{\mathrm{a}}$ \\
$\mathrm{SPH}(3-10 \mathrm{kDa})$ & $156.21 \pm 1.81^{\mathrm{b}}$ \\
$\mathrm{SPH}(10-30 \mathrm{kDa})$ & $171.95 \pm 15.35^{\mathrm{b}}$ \\
$\mathrm{SPH}(>30 \mathrm{kDa})$ & $387.82 \pm 10.77^{\mathrm{c}}$ \\
\hline
\end{tabular}

SPI: intact soybean protein; SPH: hydrolyzed soybean protein. Values are mean $\pm \operatorname{SEM}(n=3)$, and no letters in common are significantly different $(P<0.05)$.

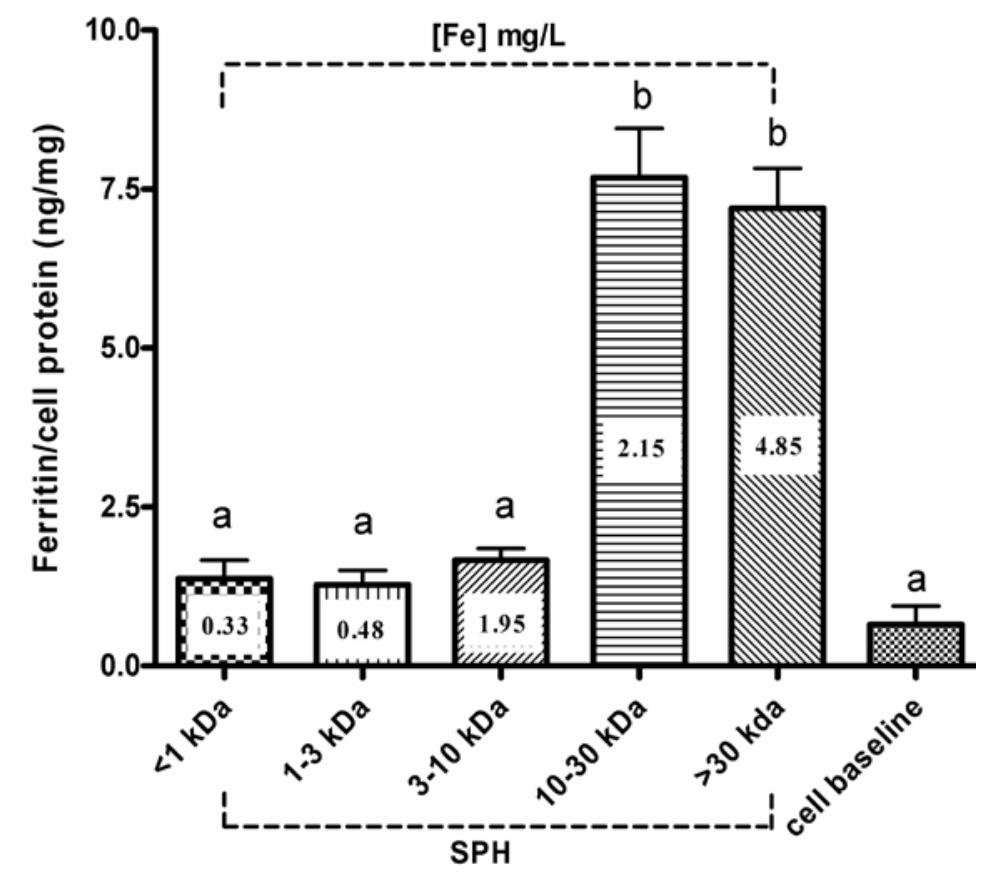

Figure 3. Cell ferritin formations in response to intrinsic iron of SPH with different molecular weight. The iron concentration of all the samples is marked in the column. Values are mean \pm SEM $(n=6)$. Bars with no letters in common are significantly different $(P<0.05)$

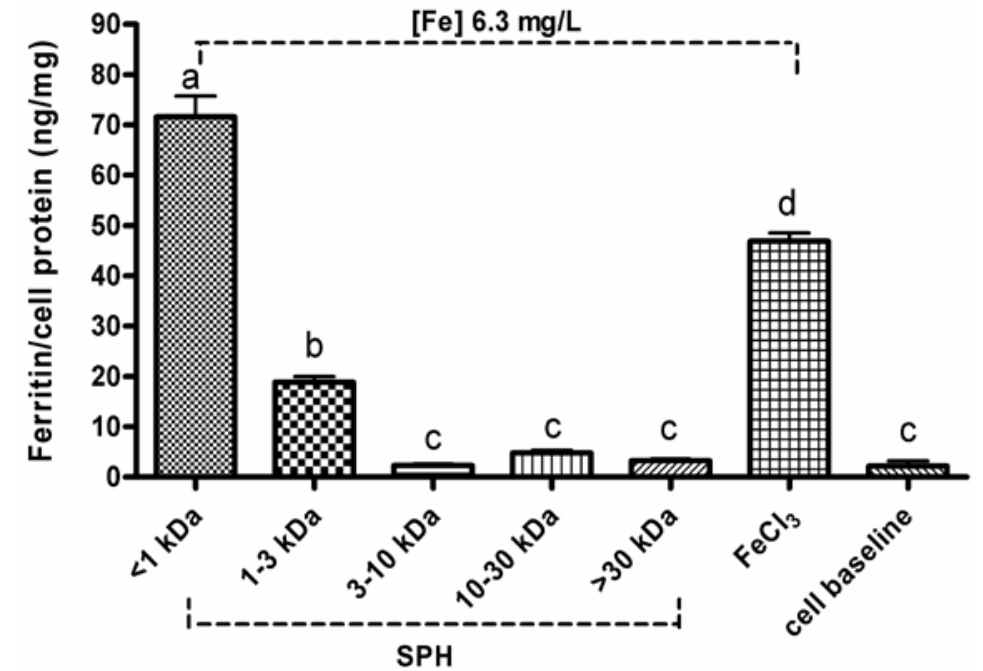

Figure 4. Cell ferritin formation in response to extrinsic iron added in SPH with different molecular weight. The final iron concentration of all the samples is $6.3 \mathrm{mg} / \mathrm{L}$. Values are mean $\pm \operatorname{SEM}(n=6)$. Bars with no letters in common are significantly different $(P<0.05)$ 
It was reported that high molecular weight of soybean protein $(>12 \mathrm{kDa})$ had an inverse relationship with iron absorption. However, no statistically significant relationship was observed between low molecular weight of SPH ( $<12 \mathrm{kDa})$ and iron absorption [3]. High molecular weight of soybean protein may bind iron tightly. When the iron content was not high enough to provide the binding iron for high molecular weight of SPH, it is impossible for the SPH $(<1 \mathrm{kDa})$ to bind with iron or promote iron uptake. Hence, even after being hydrolyzed, the uptake of intrinsic iron in SPH was just increased by 25\% (Figure 1). When additional iron was added, the iron bioavailability of partially hydrolyzed soybean protein significantly improved (Figure 2). Soy sauce was reported to promote iron absorption after iron fortification. However, soy sauce can not overcome the strong inhibition of iron absorption from soy flour (containing high molecular weight of soybean protein), while the iron absorption in the rice meal added with soy sauce was significantly improved [4]. Thus, the iron bioavailability in soybean products may depend on not only the degree of protein hydrolysis but also the iron content. Figure 4 showed that, compared with $\mathrm{FeCl}_{3}(6.3 \mathrm{mg} / \mathrm{L})$, although the $\mathrm{SPH}(<1$ $\mathrm{kDa}$ ) exhibited greater iron uptake by Caco-2 cells, $\mathrm{SPH}$ (1-3 kDa, 3-10 kDa, 10-30 kDa, and >30 kDa) still inhibited iron uptake even with additional iron. Then, it seems difficult to observe a conclusion about the relationship between iron bioavailability and low molecular weight of soybean protein fraction $(<12 \mathrm{kDa})$. However, from above results, when iron was high enough, the low molecular weight of soybean peptides $(<1 \mathrm{kDa})$ could show their enhancing role on iron bioavailability.

Many studies have reported the role of low molecular weight of fraction on iron bioavailability. It was reported that low molecular weight factor $(<10 \mathrm{kDa})$ in human milk promote iron bioavailability, and it rules out that high molecular weight of lactoferrin might be the main iron enhancing fraction in human milk [17]. In casein peptides studies, peptides with molecular weight of 1 to 5 $\mathrm{kDa}$ formed during in vitro digestion, as well as the synthetic $\beta$-casein six peptides, were all shown iron promoting effect [9]. Also it was demonstrated that low molecular weight of peptides rich in Cys enhanced iron uptake in Caco-2 cells [15]. Soybean protein contains a high amount of Asp and Glu, which can also bind with iron [11]. Thus, it is reasonable to assume that the low molecular weight of soybean peptides hydrolyzed from proteolytic digestion could promote iron bioavailability.

\section{Conclusions}

This study has examined the effect of hydrolysis on iron bioavailability of soybean protein with an in vitro digestion/Caco-2 cell model. The results clearly presented that iron bioavailability was significantly increased by $\mathrm{SPH}$ when extrinsic iron was added, and the low molecular weight of SPH could play an important role.

\section{Acknowledgements}

This work was supported by USDA-Agricultural Research Service, the Chinese National Key Technologies Research and Development Program (2012BAD34B03) and the Research Program of Beijing University of Agriculture (GJB2013005).

\section{References}

[1] Lynch, S. R., Dassenko, S. A., Cook, J. D., Juillerat, M. A. and Hurrell, R. F., "Inhibitory effect of a soybean-protein--related moiety on iron absorption in humans," Am J Clin Nutr, 60(4). 567572. 1994.

[2] Schricker, B. R., Miller, D. D. and Campen, D. V., "Effects of iron status and soy protein on iron absorption by rats," J Nutr, 113. 996-1001. 1983.

[3] Macfarlane, B. J., Riet, W. B., Bothwell, T. H., Baynes, R. D. and Siegenberg, D., "Effect of traditional oriental soy products on iron absorption,” Am J Clin Nutr, 51. 873-880. 1990.

[4] Fidler, M. C., Davidsson, L., Walczyk, T. and Hurrell, R. F., "Iron absorption from fish sauce and soy sauce fortified with sodium iron EDTA,” Am J Clin Nutr, 78. 274-278. 2003.

[5] Chen, J., Zhao, X., Zhang, X., Yin, S., Piao, J., Huo, J., Yu, B., Qu, N., Lu, Q., Wang, S. and Chen, C., "Studies on the effectiveness of NaFeEDTA-fortified soy sauce in controlling iron deficiency: A populationbased intervention trial," Food Nutr Bull, 26(2). 177186. 2005.

[6] Huo, J., Sun, J., Miao, H., Yu, B., Yang, T., Liu, Z., Lu, C., Chen, J., Zhang, D., Ma, Y., Wang, A. and Li, Y., "Therapeutic effects of NaFeEDTA-fortified soy sauce in anaemic children in China," Asia Pac J Clin Nutr, 11(2). 123-127. 2002.

[7] Baynes, R. D., Macfarlane, B. J., Bothwell, T. H., Siegenberg. D., Bezwoda, W. R., Schmidt, U., Lamparelli, R. D., Mayet, F. and Macphail, A. P., "The promotive effect of soy sauce on iron absorption in human subjects.” Eur J Clin Nutr, 44. 419-424. 1990.

[8] Bæch, B. S., Hansen, M., Bukhave, K., Jensen, M., Sørensen, S. S., Kristensen, L., Purslow, P. P., Skibsted, H. L. and Sandström, B., "Nonheme-iron absorption from a phytate-rich meal is increased by the addition of small amounts of pork meat.” Am J Clin Nutr, 77. 173-179. 2003.

[9] Argyri, K., Miller, D. D., Glahn, R. P., Zhu, L. and Kapsokefalou, M., "Peptides isolated from in vitro digests of milk enhance iron uptake by Caco-2 cells,” J Agric Food Chem, 55. 10221-10225. 2007.

[10] Argyri, K., Tako, E., Miller, D. D., Glahn, P. R., Komaitis, M. and Kapsokefalou, M., "Milk peptides increase iron dialyzability in water but do not affect DMT-1 expression in Caco-2 cells," $J$ Agric Food Chem, 57. 1538-1543. 2009.

[11] Lv, Y., Lu, Q., Bao, X., Tang, W., Yang, B. and Guo, S., "Identification and characteristics of iron-chelating peptides from soybean protein hydrolysates using IMAC-Fe ${ }^{3+}$," J Agric Food Chem. 57. 4593-4597. 2009.

[12] Sorgentini. D. A., Wagner, J. R. and Añón, M. C., "Effects of thermal treatment of soy Protein isolate on the characteristics and structure-function relationship of soluble and insoluble fractions," J Agric Food Chem, 43. 2471-2479. 1995.

[13] Glahn, R. P., Lee, O. A., Yeung, A., Goldman, M. I. and Miller, D. D., "Caco-2 cell ferritin formation predicts nonradiolabeled food iron availability in an in vitro digestion/Caco-2 cell culture model," J Nutr, 128. 1555-1561. 1998.

[14] Yeung. A. C., Glahn, R. P. and Miller, D. D., "Effects of iron source on iron availability from casein and casein phosphopeptides,” J Food Sci, 67. 1271-1275. 2002.

[15] Glahn, P. R. and Van Campen, R. D., "Iron uptake is enhanced in caco-2 cell monolayers by cysteine and reduced cysteinyl glycine," J Nutr, 127. 642-647. 1997.

[16] Storcksdieck, S., Bonsmann, G. and Hurrell, R. F., "Iron-binding properties, amino acid composition, and structure of muscle tissue peptides from in vitro digestion of different meat sources," J Food Sci, 72. 19s-29s. 2007.

[17] Etcheverry, P., Miller, D. D. and Glahn, R. P., “A low-molecularweight factor in human milk whey promotes iron uptake by Caco2 cell,” J Nutr, 134. 93-98. 2004. 